\title{
各種実験潰瘍と胃壁微小循環
}

\author{
九州大学第 2 外科* \\ ハーネマン大学外科 \\ 杉町 圭藏* 松元輝 夫 \\ マイク・ワイス カーレス・ロード
}

\section{MICROVASCULAR RESPONSES TO VARIOUS EXPERIMENTAL GASTRIC ULCERS}

\section{Keizo SUGIMACHI, M.D., Teruo MATSUMOTO, M.D., Ph.D., Mick J. WEISS and Charles RHOAD}

The Hahnemann Medical College and Hospital of Philadelphia, Pa. U.S.A.

\begin{abstract}
われわれは胃壁の微小血管の変化がストレス潰場においては重要な発生因子となっていることを報告し

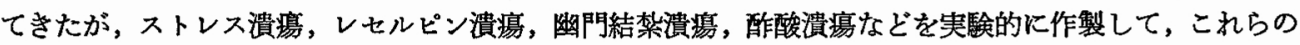
実験漬晹と胃壁徽小循環との関係を明らかたした。

まず, ウイスター系雄ラットを用いて, 各種実験潰瘍作製後, 黄色マイクロフィルを胸部大動脈より, また白色マイクロフィルを門脈より $120 \mathrm{cmH}_{2} \mathrm{O}$ の匠で注入した。 マイクロフィルが完全に血管内で㠜固 したところで胃を取り出し，厚さ約 $100 \AA$ の切片を作成し胃壁の 微小血管を観察し，各種実験潰湟に和け る胃壁の微小循環の差異を比較検討した.
\end{abstract}

索引用語：胃壁微小㡒環

はじめに

ある種の刺激を加觉ることにより胃潰瘍が発生するこ とは，臨林的・実験的にすでによく知られているところ であり，その発生機序については多くの報告がみられ

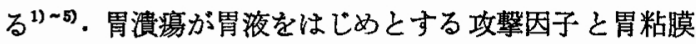
の防御因子との間のアンバランスによって発生すること は嶷う余地がないところであるう．しかし，攻撃因子の 中にも多くの種類があり，攻撃因子が異なることによ り，また発生する潰瘍む異なってくるものと思われる。

われわれは胃壁の徴小血管の収縮がストレス潰瘍に抽 いては重要な発生因子になっていることをすでに報告の

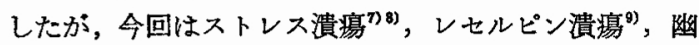

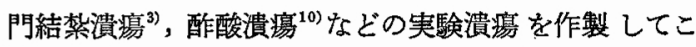
れら各種実験潰瘍と胃壁微小循環との関係を明らかにし た.

\section{実験材料およひ方法}

体重180から200g の雄のウイスターラット100匹を使 用した. 実験に先がけて24時間は水以外の固型飼料を与 党なかった．各群20匹として次の 5 群に分けた。
第 1 群：対照群（正常ラット）

第 2 群 : ストレス謴湯群；シットを金網で作った筒の 中に 1 匹づつ入れ， $4{ }^{\circ} \mathrm{C}$ 冾室に 3 時間放置した.

第 3 群 : レセルピン潰緜群 ; $8 \mathrm{mg} / \mathrm{kg}$ のレセルピンを 腹脆内飞投与し， 3 時間および24時間後に啳殺した。

第 4 群：幽門結禁潰瘍群 (Shay's ulcer); 開腹下飞幽 門を 4ー0 絹系で結紫して，24時間後に胃を摘出した。

第 5 群：酶酸潰瘍； $20 \%$ の酢酸を $0.02 \mathrm{ml}$ 胃前庭部前 壁の漿腹下に注射し，5 日後に屠殺した。

胃壁血管の形態学的観察を行うにあたり, 各群20匹を 2 群に分けた。まず10匹については黄色 (MV-122) と白色 (MV-130)の 2 種類のマイクロフィルを胸部大 動脈と門脈から注入した。すなおち，エーテル麻醉下に 正中線で開腹・開胸を行い, 胸部大動脈に22号のテフロ ンカテーテルを挿入した. このカテーテルからへパリン 生食 $(5,000$ 単位 $/ 1,000 \mathrm{ml})$ を $120 \mathrm{cmH}_{2} \mathrm{O}$ の压で注入 乙, 同時に右心房を切開 して, 血液と注入液を排出し た。排出液が透明になり，血液が完全になくなるまでへ パリン生食で洗浄した後, 22 号のテフロンカテーテルを 
閶脈にも挿入した。まず, 最初のカテーテルを通して黄 色のマイクロフィルを $120 \mathrm{cmH}_{2} \mathrm{O}$ の圧力で胃や十二指 腸が黄色となるまで約4〜 $5 \mathrm{ml}$ 注入した.つぎに，白色 のマイクロフィルを門脈に挿入しているカテーテルを通 して注入した. 残りの10匹のラットには黄色のマイクロ フィルを動脈内のカテーテルから前と同じ方法で注入 した． $4 \sim 5$ 時間後にマイクロフィルが血管内で凝固し たところで胃を摘出し，冷蔵庫の中に24時間保存し， マイクロフィルの凝固をより完全なるのとした。つぎ に，胃の長軸にそって厚さ約 $100 \AA$ の切片を作成し胃壁 の微小血管を観察した。

\section{結 果}

第 1 群の正常ラットの胃壁の血管構築は图 1 のごと く, 動脈 (A) から細動脈 (CA) となり，粘膜の基底 部で毛細管 (C) へと移行している。一方, 毛細管は図 2 のごとく胃粘膜表面で蜂の 巣状の 分布をしたのち,

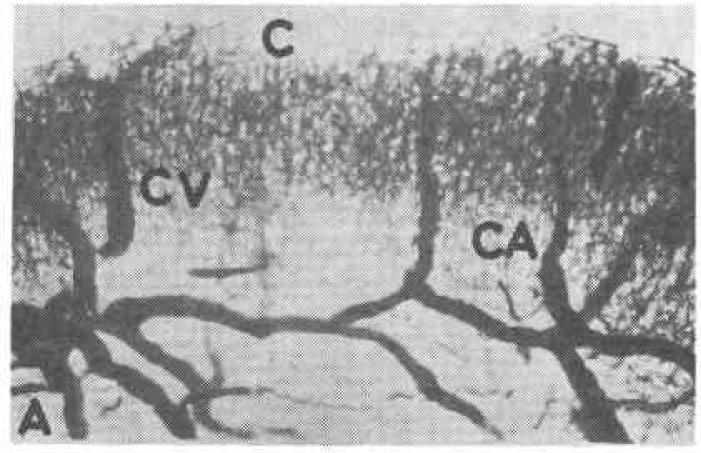

図 1 正常ラット胃壁の血管椪筑 $(\times 40)$
A : 動 脈
$\mathrm{CA}:$ 練動脈
C : 細 管
CV : 細静脈

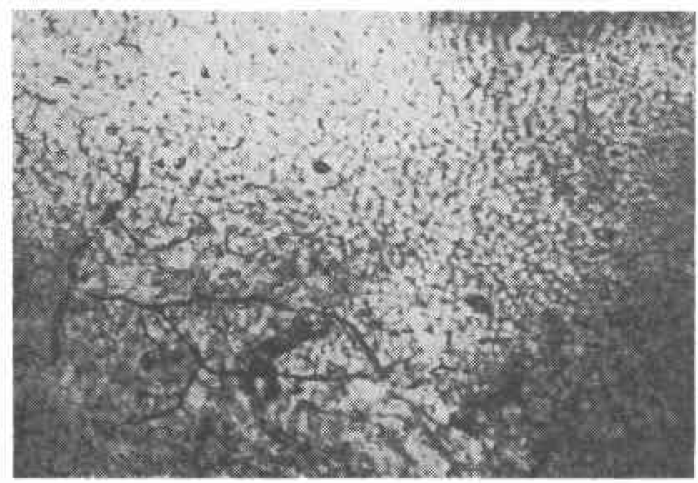

図 2 正常 $ッ$ トの胃粘膜面 $(\times 40)$ 正常粘膜は蜂の巣状の規則正しい構造である.

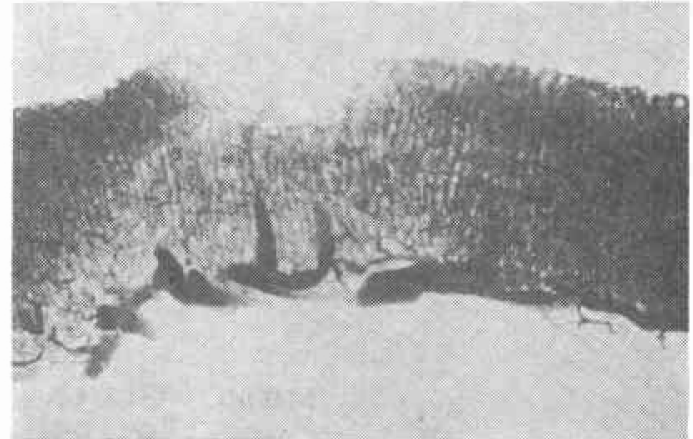

因 3 ストレスを加えたラットの胃壁 $(\times 40)$ 毛細管の一部にはマイクロフィルが入らない部分が みられる。

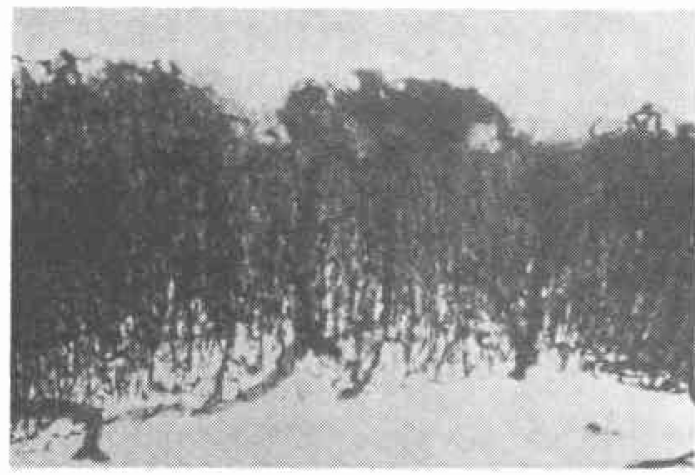

図 4 ストレス溃瑒よりの出血 $(\times 40)$

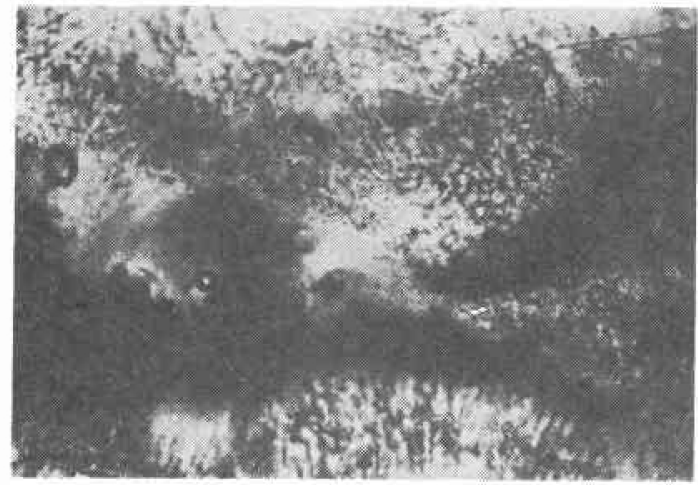

図 5 ストレス潰瘍の粘膜面 $(\times 40)$

細静脈 $(C V)$ へ注ぐ.

第 2 群 (ストレス潰瘍) では，ラットを 3 時間 $4{ }^{\circ} \mathrm{C} の$ 冷室に放固することにより，多くの浅い急性潰瘍が発生 した．粘膜表面の毛細血管は図 3 のごとくマイクロフィ ルが十分に入らない部分やまた図 4 のごとく粘膜面の出 血斑が見られた，出血部位を粘膜表面からみると図 5 の 


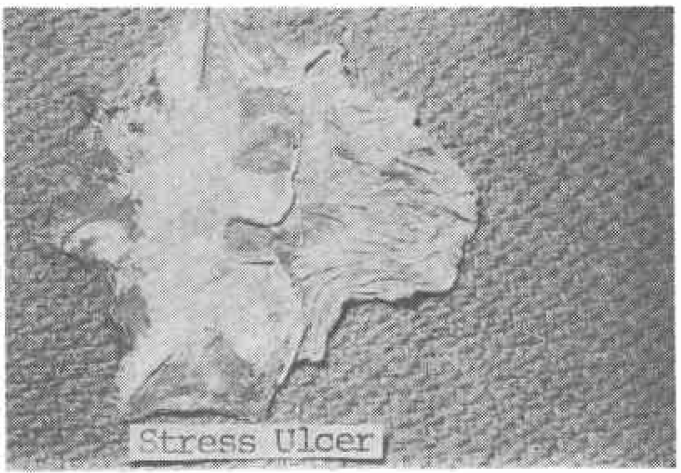

图 6 ストレス潰場

白色と黄色がマイクロフィルが潰癔から流出している。

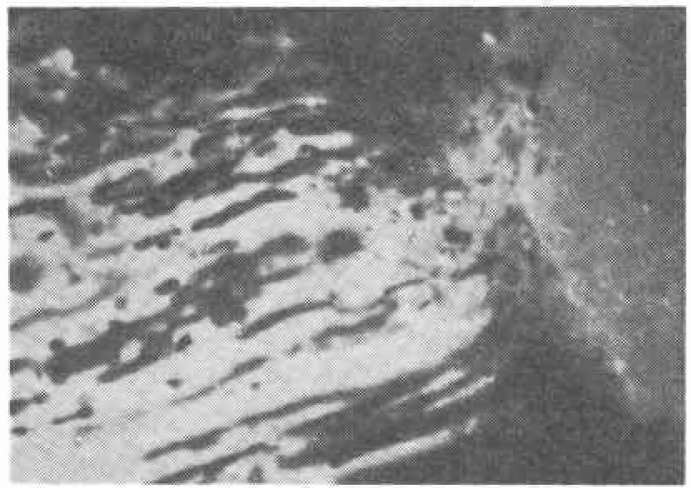

図 7 レセルピン注射後 3 時間

目の胃壁毛細血管の 狭小化を認める。（×80）

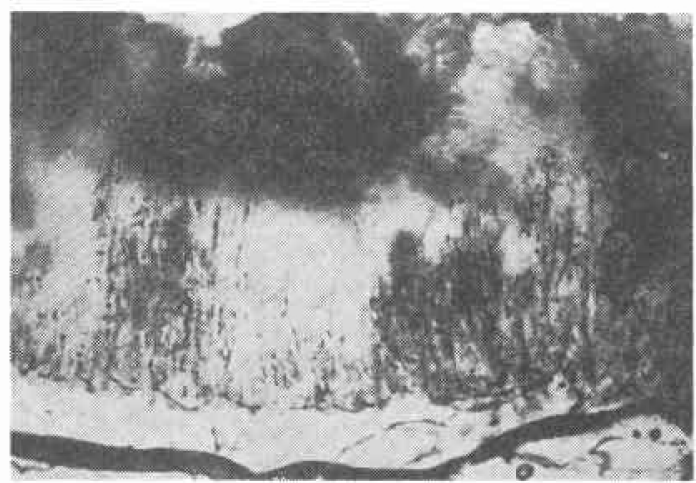

因 8 レセルピン潰湟

胃壁血管の狭小化と出血を認める。 $(\times 40)$

ごとくその附近の粘膜にはマイクロフィルが十分に漫透 していない事がわかる。ストレス漬瘍では黄色と白色の マイクロフィルが潰瘍表面に浸出してきた（図6）.

第 3 群（レセルピン潰瘍）では，レセルピン注射後 3

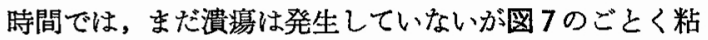

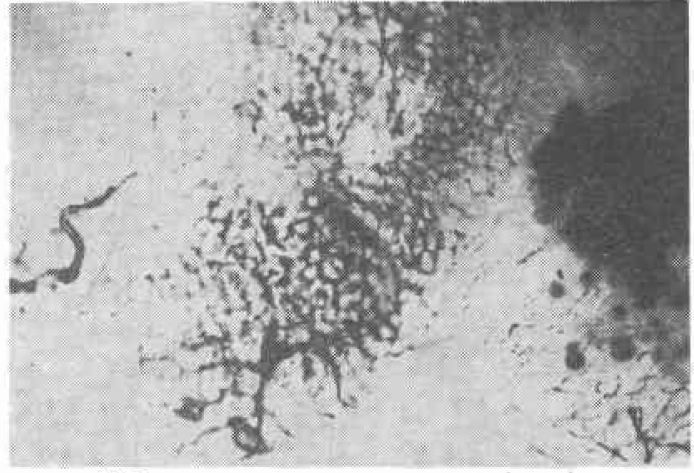

图 9 レセルピン潰湯の粘膜面 $(\times 40)$

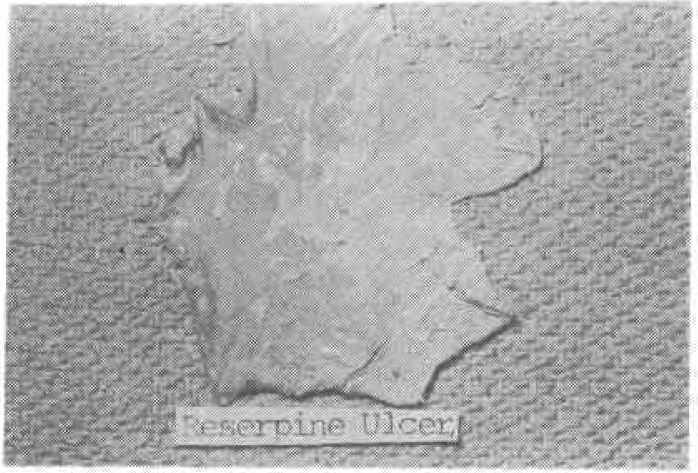

図10 レセルピン溃瘍

主として黄色のマイクロフィルが漬瘍面より流出 している.

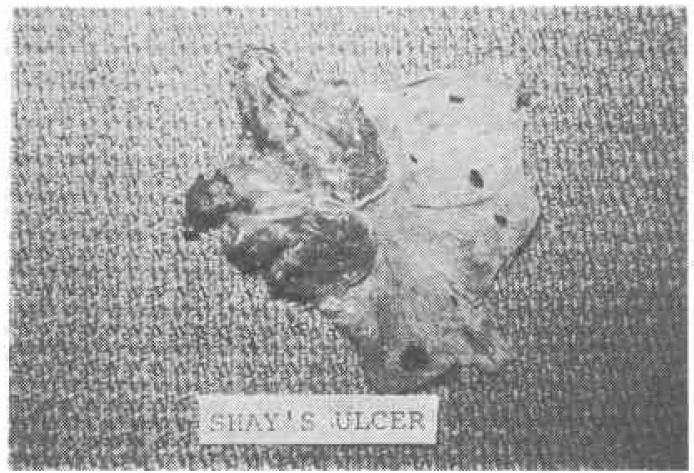

\section{図11幽門結紮謴演}

胃膜様部に潰演が発生する。

膜層の毛細血管に著しい変化を認めている．24時間後に は図 8 のごとく出血斑を伴った潰瘍と毛細管や細動脈を 中心として著しい阻血がみられる、粘膜の表面像では， ごく一部の毛細管にはマイクロフィルが入っているが， 多くの毛細管にはマイクロフィルが入っていない図 9). また粘膜表面に漫出してきたマイクロフィルは 図100ごとく主として黄色のマイクロフィルであった。 


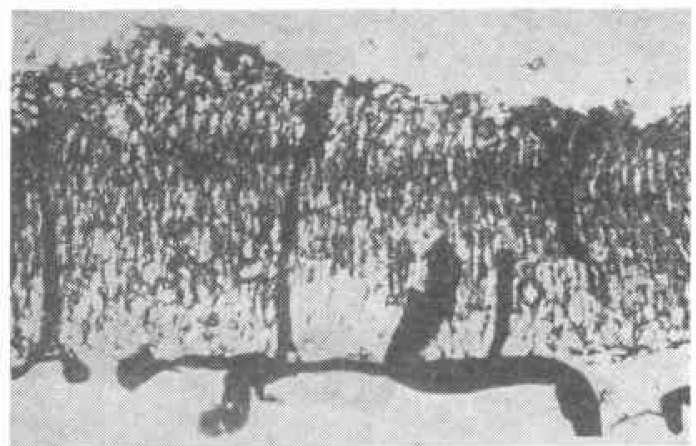

图12 幽門結紮演湯

マイクロフィルは毛細血管まで十分に入り込んで いる.

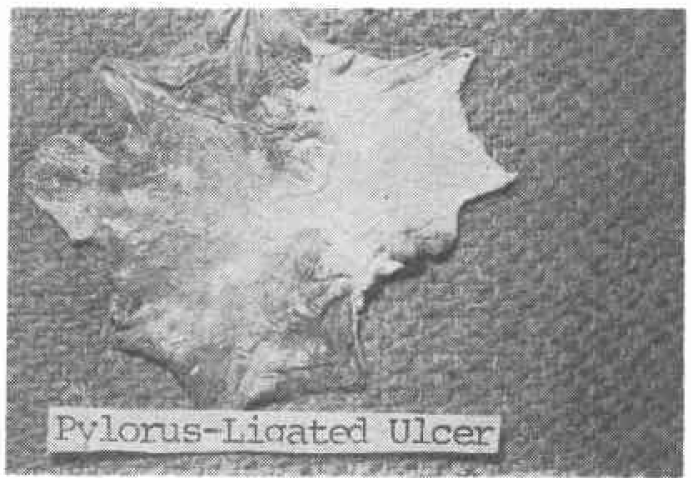

因13幽門結禁溃汮

主として白色のマイクロフィルが潰䁑面より流出 している.

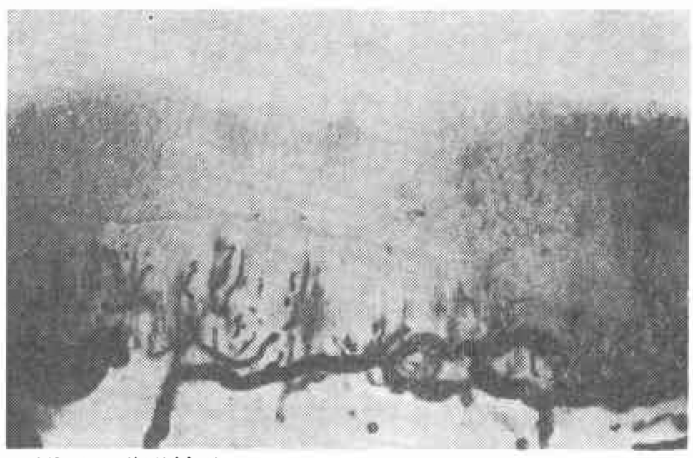

図14 酢酸潰瘍

すべての血管が著しい変化を受けている。

第 4 群（幽門結禁潰瘍）：20匹のらち 2 匹は24時間以 内に㵑瘍穿孔のため死亡した。すべての潰瘍は膜様部に の㷅発生して括り（図11)，マイクロフィルは毛細管ま でよく入り込み，腺状部の粘膜面には異常を認めなかっ た(図12).また，潰淘面には図13のごとく主として白 色のマイクロフィルが流出した。

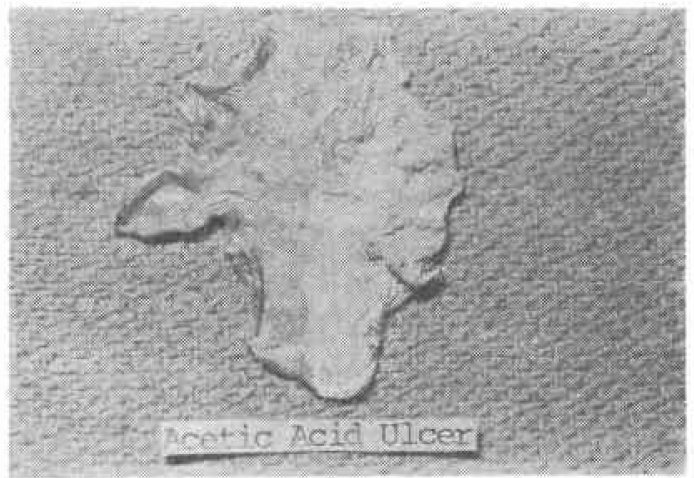

\section{因15 酢酸潰湯}

白色と黄色のマイクロフィルが溃湟面より流出し $\tau<る$.

第 5 群（酢酸潰瘍）：図14のごとく，潰瘍周辺では強 い浮腫がおこり細動脈・毛細管はマイクロフィルで満た されることなく，胃壁全層が強い方血状態になっている ことがわかる。また，潰瑒面から流出してきたマイクロ フィルは黄色と白色の両者であった（図15）.

\section{考 察}

胃潰場の成因に関して，現在なおいくつかの仮説があ $ろ^{13)}$. その第 1 は幽門部の異常により十二指腸への食物 の䔟行が遅れ，しかも胃夜の分泌が増加して潰場の発生 につながるという考方方である ${ }^{14) 15)}$ ．これは胃潰瘍の成 因の中で重要なむのの1つであり臨床的幽門狭窄があ った切除胃では，胃粘膜に浅い糜爛がよくみられるのる この成因によっているものであるう。また，幽門結禁に より作成した笑験潰湯もこの成因でできたすのと考光ら れる.幽門結禁潰瘍は膜様部のみに発生するが，これは この部分が扁平上皮で被われて扔り ${ }^{3)}$ ，胃液に対する抵 抗性が腺状部に比べて弱いためであろう。ささらに，この 幽門結禁潰場では胃壁の微小循環に何らの変化を見出し ていない。これらのことから幽門結禁潰瘍はストレス潰 瘍，レセルピン潰瘍なと゚と全く異なった成因を有してい ることがわかる。

第 2 の仮説は胃のパリアーの異常により胃潰瘍が発生 するというもので, これは胃の分泌が少ないにもかかわ らず，みられる慢性潰瘍の成因と考えられる。

第 3 の仮説怯天先天的飞胃粘膜の弱、部分に潰瘍が発生 するというもので，とくに，胃小弯側に発生した潰演が これによるものであちら ${ }^{1920)}$.

一方，胃潰場はストレスにより，実験的にむ臨床的に あ容易に発生することはよく知られているところである が(6) 21)，その発生機序についてはまだほとんど判明して 
いない.この実験でラットにストレスを加党たことによ り，多数の浅い出血を伴った急性潰陽が発生し，しかも 粘膜の毛細血管にはマイクロフィルが侵入しにくいこと が明らかになった。この粘膜の乏血性変化がストレス潰 瘍の発生に極めて深い関係を有して抢り，われわれはこ の胃壁微小循環の変化を第 4 番目の仮説としたい。 たレセルピン注射後 3 時間ですでに毛紐血管のみでな く細動脈の狭小化がみられるが，この時点ではまだ潰湟 の発生がみられていない. 注射後24時間経つとストレス 潰瘍よりる深い潰瘍が発生しており，主として動脈側の 血管破綻が証明された，以上のごとく，われわれは潰瘍 発生に関係していると思われる胃壁血管の变化を明らか にした. しかし，これらの血管の変化は胃潰瘍の原因で はなく，その結果であるとも考光られるかるしれない。 ところが，（1）実験潰瘍の種類により，表1のごと く，胃壁血管の変化にも違いがあること，（2）レセル ピン注射後 3 時間ではまだ潰瘍は発生していないが，す でに微小血管に変化を認めること，（3）表 2 や図160

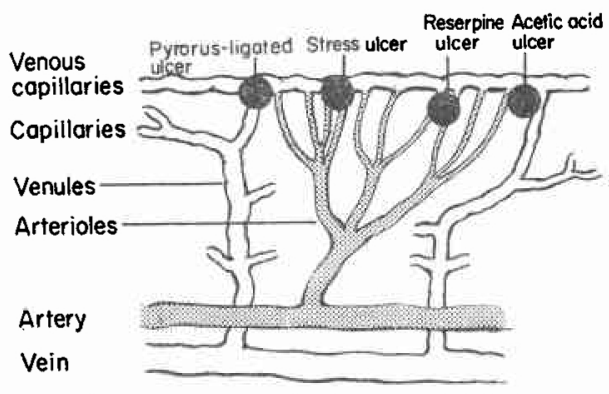

因16 各種実験潰瘍の血管破糘部位

表 1 各種実験潰浧における胃壁微小循環の变化

\begin{tabular}{|c|c|c|c|c|c|}
\hline 血管 & 対照 & 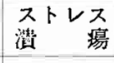 & $\begin{array}{l}\text { レセルピン } \\
\text { 潰 㶘 }\end{array}$ & $\begin{array}{l}\text { 幽門結㮃 } \\
\text { 潰 晹 }\end{array}$ & 酰酸资㾴 \\
\hline Artery & 0 & 0 & + & 0 & $H$ \\
\hline Arteriole & 0 & + & H & 0 & $H$ \\
\hline Capillary & 0 & H & $H$ & 0 & H \\
\hline $\begin{array}{l}\text { Collecting } \\
\text { Venules }\end{array}$ & 0 & + & 0 & 0 & H \\
\hline $\begin{array}{l}\text { Collecting } \\
\text { Vein }\end{array}$ & 0 & 0 & 0 & 0 & + \\
\hline
\end{tabular}

血管の変化 0 : 变化なし, + ：軽度，＋：中等度

表 2 潰崲面からのマイクロフィルの侵出

\begin{tabular}{|c|c|c|c|c|c|}
\hline 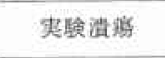 & 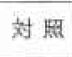 & ストレス & $\begin{array}{l}\text { レ゙ルピy } \\
\text { 海 基 }\end{array}$ & 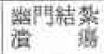 & 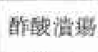 \\
\hline $\begin{array}{l}\text { 血管外侵出マイ } \\
\text { ロフルの色 }\end{array}$ & \& L & 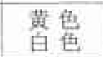 & 黄色 & 自色 & 黄焦 \\
\hline
\end{tabular}

ごとく, 潰瘍の血管破綻には動脈側, 動・静脈両側, 静 脈側などが実験潰湟の種類によって異なっていること， などは胃壁の血管変化が潰瘍の結果ではなく，むしろ原 因であることを強く示唆しているものと考穴ている.

酢酸潰瘍に沶いて子動・静脈の強い狭小化を認めた が，これは䣷酸による潰瘍周辺の強い浮尰によるものと 思われる。

臨床的には，このような胃壁血管の変化が胃潰場発生 の原因となっているかどうかは断定できないがこえら の実験結果は胃潰瘍の成因の 1 つとて胃壁の微小血管 の変化が重要であることを示唆しているすのと考えてい る。

$$
\text { まとめ }
$$

マイクロフィルを用いてラットのストレス，レセルピ ン，幽門結禁，酢酸潰瘍における胃壁の微小循環の美異 を実験的に研究した。

ストレス潰瘍では胃粘膜の毛細管の㹟小化がおこって 和り，潰瘍からの出血は動脈・静脈両側からおこってい る、レセルピン潰瘍では胃粘膜の毛細管だけでなく細動 脈にも狭小化あるいは閉塞を認めており，潰湯からの出 血は主として動脈側からの出血であった．幽門結禁潰瘍 では微小血管に著変を認めず，ストレス潰瘍，レセルピ ン潰場とはその発生機序が異なることが判明した. 酢酸 潰瘍では潰瘍周辺の浮腫が強く動・静脈ともに著しく圧 迫されていた．以上，われわれはある種の実験潰瘍に和 いては胃の徽小循環の变化が胃潰瘍の発生と極めて関係 深いことを明らかにした。

\section{文献}

1) Spino, H. and Milles, S.: Steroid-Induced Peptic Ulcer, N. Eng. J. Med., 263: 286-294, 1960.

2) Broodie, D.: Experimental Peptic Ulcer, Gastroenterology, 55: 125 - 134, 1968.

3) Shay, H., Komarov, S.A., Meranze, D., Gruenstein, M. and Siplet, H.: A Simple Method for Uniform Production of Gastric Ulceration in Rats, Gastroenterology, 5: 43-61, 1945.

4) Levine, R.J. and Senay, E.C.: Studies on the Role of Acid in the Pathogenesis of Experimental Ulcers, Psychosomatic Medicine, 32: 61-65, 1970.

5) Guth, P.H. and Smith, E.: Neural Control of Gastric Mucosal Blood Flow in the Rat. Gastroenterology, 69: 935-940, 1975.

6) Kawarada, Y., Lamek, J. and Matsumoto, T.: Pathophysiology of Stress Ulcer and Its Preven. tion. II Prostagandin $\mathrm{El}$ and Microcirculatory 
Reponses in Stress Ulcer, Am. J. Surg., 129: $217-$ 222,1975

7) Lucas, E.E., Sugawa, C. and Walt, A.J.: Natural History and Surgical Dilemna of Stress Gastric Bleeding, Arch. Surg., 120: 266-273, 1971.

8) Kawarada, Y., Weiss, R. and Matsumoto, T. Pathophysiology of Stress Ulcer and Its Preven. tion. I Pharmacologic Doses of Steroid, Am. J. Surg., 129: 249-254, 1975.

9) Watanabe, I.: Reserpine Ulcer, Experimental Ulcer, 2: 36-38, 1975.

10) Okabe, S.: A Chronic Gastric Ulcer Model; Acetic Acid Ulcer, Experimental Ulcer, 2: 47-49, 1975.

11) Selkurt, F.M.: Hemodynamics of Intestinal Circulation, Circulation Res., 6: 92-99, 1958.

12) Turner, M.W.: The Effect of Temporary Arterial, Venous, and Arteriovenous Occlusion upon Intestinal Blood flow, Surg. Gene. Obst., 108: $347-350,1959$.

13) Rhodes, J.: Etiology of Gastric Ulcer, Gastroenterology, 63: 171-- 182, 1972.

14) Dragsted, L.R. and Woodward, E.R.: Gastric Stasis, A Cause of Gastric Ulcer, Scand. J.
Gastroentrology, 5: 243-252, 1970.

15) Burger, H.: The Etiology of Benign Lesser Curve Gastric Ulcer; Vagotomy and Phyoroplasty in Its Treatment, Ann. R. Coll. Surg. Engl., 38: 349$360,1966$.

16) Duplessis, D.J.: Pathogenesis of Gastric Ulceration, Lancet, 1: 974-978, 1965.

17) Capper, W.M.: Factors in the Pathogenesis of Gastric Ulcer, Ann. R. Col. Surg. Engl., 1: $21-$ 29, 1967.

18) Capper, W.M., Butler, T.J. and Buckler, K.G.: Alkalkine Areas in Gastric Mucosa After Gastric Surgery, Gut., 7: 220-235, 1966.

19) Lawson, H.H.: Gastritis and Gastric Ulceration, Br. J. Surg., 53: 493-496, 1966.

20) Ritchie, W.P. and Delaney, J.P.: Pathogenesis of Gastric Ulcer; An Experimental Model, Surg. Forum, 19: 321-315, 1968 .

21) Fletcher, D.G., Harkins, H.N. and Wash, S.: Acute Peptic Ulcer As A Complication of Major Surgery, Stress, or Trauma, Surgery, 36: 212 -$216,1954$. 